\title{
SOCIAL MEDIA IN THE MARKETING COMMUNICATION OF POLISH BANKS
}

\author{
AGNIESZKA BUDZIEWICZ-GUŹLECKA, ${ }^{1}$ MARIUSZ WOŹNIAKOWSKI ${ }^{2}$
}

1 University of Szczecin, POLAND

e-mail: agnieszka.budziewicz@wzieu.pl

2 University of Lodz, POLAND

e-mail: mariusz.wozniakowski@uni.lodz.pl

RECEIVED
ACCEPTED
JEL
CLASSIFICATION

KEYWORDS

ABSTRACT
27 November 2017

5 January 2018

$\mathrm{G} 21, \mathrm{M} 35,016,035$

social media, banks, marketing communication, Internet communication

Social media are one of the most flexible and dynamic tools of the Internet, which stems from the fact that they offer bidirectional communication. They enable banks to individualize the process of marketing communication and conduct the kind of communication with clients on the market that resembles a dialog. The aim of this article is to identify social media in the marketing communication of banks in Poland. This article presents the essence of these media to subsequently focus on the role of social media in the activity of banks. It also verifies the scope of using social media by major banks. Further, it analyzes the contents of websites and social media profiles of the banks included on "The 500 List” ("Lista 500”) of the largest Polish businesses. The list features 19 banks. This particular ranking has been applied due to the fact that large banks often pioneer the implementation of new methods of communication, including the use of social media. They also have appropriate resources to conduct communication activities on a large scale. The results of the analysis of website contents and social media profiles of banks have been presented in the article.

\section{Introduction}

Social media enable banks to individualize the process of marketing communication and conduct the kind of communication with clients on the market that resembles a dialog in a way that was previously unheard-of. Social media create a virtual image of an organization and help build lasting relations with clients. The aim of this article is to attempt to identify social media in the marketing communication of banks in Poland. The article puts forward 
the following research hypothesis - Commercial banks operating in Poland actively use social media in the process of marketing communication. In reference to the aim and hypothesis adopted in this article, the following research question has been posed - Which banks in Poland pioneer the implementation of new methods of communication, precisely speaking, social media? In an attempt to answer this question, the article first reflects on the essence of social media. Further, it presents the role of social media in the activity of banks, particularly their marketing communication. Subsequently, it illustrates the results of the analysis of website contents and social media profiles of banks. Finally, it discusses distinctive activities of banks in social media.

\section{The essence of social media}

The Internet is the engine of today's economy as it allows businesses to build relations and develop worldwide (Drab-Kurowska, 2013, p. 302). The expansion and ever-increasing access to the Internet world-wide renders it one of the first sources when seeking information in the 21st century (Cabosky, 2016, p. 172). The frequency of using the Internet is also affected by the growth of social media, which play a major role in the transference of information about products between users.

The growth of social media is a key element of the sharing economy. They taught people to communicate quickly, effectively and easily with one another via the web (Budziewicz-Guźlecka, 2017, p. 36). It should be highlighted that any media and on-line networks enable Internet users to integrate via their individual participation.

Due to their nature, functionality, interactivity, versatility, innate potential and their ability to satisfy various needs of different groups of recipients, social media constitute a crucial platform of marketing communication in the virtual environment (Wiktor, 2013), including that applied by the banking sector.

As previously noted, social media enable communication and exchange of information with other net users. Social media, as any term in literature, is defined in a number of ways:

a) by Kaplan and Haenlein, as a group of applications based on Internet solutions. They are the ideological and technological foundations of Web 2.0 which enable the creation and exchange of contents generated by users (Kaplan, Haenlein 2010, p. 59);

b) a convenient and useful way of building interactions and cooperation with Internet users in the area of generating new information and gaining knowledge (Levy, 2009, p. 120);

c) a set of nearly free tools and Internet websites that allow a given community to generate contents and conduct a dialog on-line (Levinson, Gibson 2011, p. 17).

McQuail, on the other hand, suggested the term new media, and presented a list of features defining them as such. They include (McQuail, 2007):

- interactivity - determined by the recipient's reaction to the sender's offer. High interactivity means bidirectional communication,

- social presence - a sense of personal contact with others. Its high level is affected by the physical closeness and immediacy of communication,

- abundance - decides about the degree to which a medium is able to reduce the ambiguity of a message. The more information a medium is capable of communicating in a given time, the more abundant it is,

- autonomy - a substantial degree of independence from the sender and the ability for one's own interpretation of a message,

- playfulness - focus on entertainment and pleasure rather than usefulness, 
- privacy - their use is not purely instrumental but is often of emotional nature,

- personalization - adjusting the message to the recipient.

\section{The role of social media in the activity of banks}

Competitiveness of banks is identified with efficiency, productivity and effectiveness. Competitiveness, aside from numerous other factors, is influenced by banks' use of social media.

The society's digitalization results in an increasing role for retail banking. Clients tend to change banks or use the services of more than one financial institution. Consumers expect products to be adjusted to their individual needs. They are willing to divulge more personal information to banks in order to obtain more personalized services. Along with technological development, banks can use information which they have about their clients to create new products. Big data, social media, location-based services - these are the new tools which financial institutions must learn to apply.

The key benefits from using social media by banks include (Social Banking, 2014, pp. 6-9):

- reaching a greater number of clients and obtaining information about them,

- obtaining feedback from consumers (about an offer, a bank's image or its employees, etc.), and along with that, improving service quality,

- the opportunity to adjust the product range to users' life situation,

- the opportunity to improve the product range depending of consumers' opinions, preferences and needs,

- obtaining from clients ideas on innovative solutions and new directions for an organization to explore,

- the opportunity to conduct marketing campaigns while simultaneously reducing their total cost,

- an increased operating radius of banks and the opportunity to promote bank products,

- the opportunity to build a positive image based on clients' positive opinions,

- building customer loyalty.

The development of social networks and other channels of communication affords banks unlimited possibilities to interact with individual groups of stakeholders. The development of new technologies and the association of various socioeconomic fields are heading in the direction of engaging participants in co-deciding and co-creating. Social media and the principles of their operation are based on functionality and reach.

The mistakes committed by banks when using social media include:

1. Laziness - currently, social networks are starting to resemble the same channel of obtaining information by clients as call centers. If a bank neglects to answer a question posed on its fun page, it means ignoring a client.

2. Lies - if a bank is indeed experiencing a system failure, the worst solution is to pretend that it is not. It is not a wise move to marginalize the problems of an individual.

3. A lack of knowledge - it happens that when a client asks a specific question regarding a product and is given the wrong information; they can quickly identify that. The assumption that a client knows less than an administrator of a bank's website is completely wrong - a lot of clients are trying to stay up to date with bank offers and are well-informed about them. Communicating to them that they know less in that area may have a detrimental impact on the reception of the brand. 
4. A lack of accountability - referring clients to other information channels. If a social channel is viewed as equal to a telephone one and banks are trying to present it as a source of information and direct contact, they should minimize the risk where the profile administrator refers a client somewhere else for information.

5. Excessive graphics and advertisements.

6. Profusion - banks should also not overdo contests as the client specificity of the banking market does not approve of wasting financial means.

For safety reasons, banks cannot move all functions of a call center to social media.

\section{Social media in Polish banks - research analysis}

According to the data of the KNF (Financial Supervision Authority) (https://www.knf.gov.pl/?articleld=56224\&p_ $\mathrm{id}=18$ ), at the end of the year 2017, 35 commercial banks and 533 cooperative banks operated in Poland. Due to the volume restraints, only the scope of using social media by the largest banks has been verified for the purposes of this study. It analyzes the contents of websites and social media profiles of the banks included on "The 500 List” of the largest Polish businesses (the compilation features 19 banks), published by the Rzeczpospolita daily in April 2017. The research, conducted between 20-22 February 2018, consisted of 3 stages. First, it was checked which social media were directly linked on banks' websites (e.g. in the form of social plugins, classic hyperlinks, etc.). The findings are illustrated in Table 1.

Tahle 1. Bank profiles in social networks (as of 22.02.2018)

\begin{tabular}{|c|c|c|c|c|c|c|c|c|}
\hline \multirow{2}{*}{ No. } & \multirow{2}{*}{$\begin{array}{c}\text { Rank on } \\
\text { "Lista 500" }\end{array}$} & \multirow{2}{*}{ Name of the bank } & \multirow{2}{*}{ Website's address } & \multicolumn{5}{|c|}{ Social media plugins on the banks' websites } \\
\hline & & & & Facebook & Instagram & Twitter & YouTube & other \\
\hline 1 & 13 & PKO BP & pkobp.pl & 1 & (1) & 1 & 1 & 1 \\
\hline 2 & 34 & BZ WBK & bzwbk.pl & 1 & 1 & 1 & 1 & 1 \\
\hline 3 & 38 & Pekao SA & pekao.com.pl & 1 & (1) & (1) & 1 & - \\
\hline 4 & 61 & mBank & mbank.pl & 1 & 1 & 1 & 1 & 1 \\
\hline 5 & 63 & ING Bank Śląski & ingbank.pl & 1 & 1 & 1 & 1 & 1 \\
\hline 6 & 92 & Alior Bank & aliorbank.pl & 1 & - & 1 & 1 & - \\
\hline 7 & 94 & Bank Millennium & bankmillennium.pl & - & (1) & 1 & 1 & 1 \\
\hline 8 & 106 & Getin Noble Bank & getinbank.pl & 1 & 1 & - & 1 & 1 \\
\hline 9 & 108 & BGŻ BNP Paribas & bgzbnpparibas.pl & 1 & - & - & 1 & 1 \\
\hline 10 & 142 & Bank Handlowy w Warszawie & citibank.pl & 1 & - & 1 & 1 & - \\
\hline 11 & 146 & Credit Agricole Polska & credit-agricole.pl & 1 & 1 & - & 1 & 1 \\
\hline 12 & 148 & Raiffeisen Polbank & raiffeisenpolbank.com & 1 & - & 1 & 1 & 1 \\
\hline 13 & 205 & Bank Gospodarstwa Krajowego & bgk.pl & 1 & - & 1 & 1 & - \\
\hline 14 & 214 & Idea Bank & ideabank.pl & 1 & 1 & 1 & 1 & 1 \\
\hline 15 & 241 & Deutsche Bank & deutschebank.pl & - & - & - & (1) & - \\
\hline 16 & 293 & Eurobank & eurobank.pl & 1 & 1 & 1 & 1 & - \\
\hline 17 & 325 & Bank Ochrony Środowiska & bosbank.pl & 1 & - & 1 & (1) & 1 \\
\hline 18 & 470 & Bank BPS & bankbps.pl & 1 & - & (1) & 1 & 1 \\
\hline 19 & 500 & SGB-Bank & sgbbank.com.pl & - & - & - & (1) & - \\
\hline Total & & & & 16 & $7(10)$ & $12(14)$ & $16(19)$ & 12 \\
\hline
\end{tabular}

Explanatory notes: 1 = a profile accessed via a social plugin on the website; (1) = a profile searched via Google browser (no plugin on the company website).

Source: own study. 
In the second stage, if there was no direct link to any profile in social media in the structure of the company website, it was searched via Google browser by typing a suitable phrase, e.g. mBank Instagram, Idea Bank Twitter, etc. Such a mode of searching for profiles was applied to the four most popular social networks: Facebook, YouTube, Instagram and Twitter.

In the third stage, the previously identified profiles in social networks or other media (e.g. blogs) were analyzed with respect to the contents. Only profiles in Polish were considered due to the target recipient - a client on the Polish market. It was checked whether profiles were regularly updated, how frequent were the publications and what the tone of communication was (e.g. commercial - an offer presentation, press communiques, education, etc.).

Table 2. The characteristics of bank profiles in social networks (as of 22.02.2018)

\begin{tabular}{|c|c|c|c|c|c|c|c|c|c|}
\hline \multirow[b]{3}{*}{ No. } & \multirow[b]{3}{*}{ Name of the bank } & \multicolumn{8}{|c|}{ Name of social network } \\
\hline & & \multicolumn{2}{|c|}{ Facebook } & \multicolumn{2}{|c|}{ Instagram } & \multicolumn{2}{|c|}{ Twitter } & \multicolumn{2}{|c|}{ YouTube } \\
\hline & & 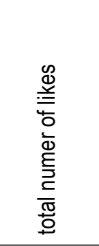 & 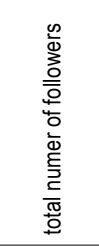 & 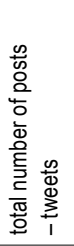 & 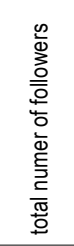 & 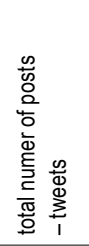 & 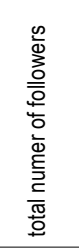 & 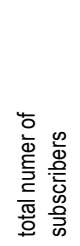 & 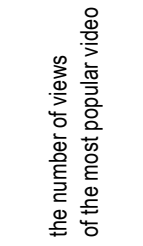 \\
\hline 1 & PKO BP & 113,836 & 111,118 & 43 & 1,005 & 5,103 & 4,611 & 3,503 & $1,919,687$ \\
\hline 2 & BZ WBK & 287,045 & 279,731 & 438 & 967 & 5,846 & 16,700 & 4,902 & $1,406,598$ \\
\hline 3 & Pekao SA & 58,952 & 58,731 & 2 & 284 & 44 & 311 & 743 & 1071,602 \\
\hline 4 & mBank & 298,145 & 290,272 & 212 & 2,631 & 10,400 & 11,800 & 7,745 & 3,824210 \\
\hline 5 & ING Bank Śląski & 222,439 & 218,089 & 207 & 4,219 & 5,029 & 17,000 & 65,277 & $3,412,540$ \\
\hline 6 & Alior Bank & 90,971 & 88,479 & - & - & 1,776 & 8,717 & 2,283 & $1,346,644$ \\
\hline 7 & Bank Millennium & - & - & 65 & 580 & 2,109 & 1,791 & 3,883 & $3,012,393$ \\
\hline 8 & Getin Noble Bank & 37,156 & 36,471 & - & - & - & - & 2,851 & $1,236,099$ \\
\hline 9 & BGŻ BNP Paribas & 209,570 & 204,186 & - & - & - & - & 1,867 & $1,747,698$ \\
\hline 10 & Bank Handlowy w Warszawie & 145,061 & 139,662 & - & - & 2,950 & 5,167 & 1,240 & $4,169,765$ \\
\hline 11 & Credit Agricole Polska & 33,250 & 32,804 & 19 & 504 & - & - & 1,061 & $1,214,769$ \\
\hline 12 & Raiffeisen Polbank & 37,798 & 37,332 & - & - & 93 & 124 & 658 & $1,246,434$ \\
\hline 13 & Bank Gospodarstwa Krajowego & 3,435 & 3,527 & - & - & 1,472 & 1,061 & 38 & 1,443 \\
\hline 14 & Idea Bank & 101,109 & 99,104 & 521 & 132 & 3,315 & 7,698 & 844 & $1,158,504$ \\
\hline 15 & Deutsche Bank & - & - & - & - & - & - & 65 & 247,549 \\
\hline 16 & Eurobank & 61,837 & 61,143 & 182 & 502 & 1,016 & 678 & 1,571 & $2,150,855$ \\
\hline 17 & Bank Ochrony Środowiska & 9,098 & 9,187 & - & - & 711 & 2,148 & 32 & 2,644 \\
\hline 18 & Bank BPS & 13,313 & 13,250 & 455 & 117 & 1,003 & 323 & 106 & 63,670 \\
\hline 19 & SGB-Bank & - & - & - & - & - & - & 333 & lack of content \\
\hline
\end{tabular}

Source: own study.

Out of 19 analyzed banks (and the same number of websites), 17 had plugins to their profiles in social networks in the structure of their website (a detailed index is included in Table 1). 16 websites had redirections to Facebook and/or Youtube, 12 - to Twitter, and 7 - to Instagram. In 12 cases, there were also redirections to other social media: 11 to Linkedln (except for mBank), 5 to a company blog (PKO BP, WBK, ING, Getinbank, Credit Agricole), 2 to a discussion forum (mBank, ING), 1 to GoldenLine (PKO BP), 1 to NK.pl (WBK) and 1 to WBK's own social network 
- the Bank of Ideas (Bank Pomysłów). Following the implementation of the second stage of the research, further bank profiles in social networks were identified (the company website offered no links to them): 3 to Instagram and YouTube, and 2 to Twitter. Ultimately, there was no bank that did not have at least one company profile in a social network. However, their distribution was surprising. While all the analyzed entities had a channel on YouTube (although SGB-Bank's had no content), only 13 banks had a profile on the most popular social network in the world Facebook. There were 14 profiles on Twitter and 10 on Instagram. According to the research methodology adopted, further profiles in other social media were not searched, hence, their status remained unchanged.

The Facebook profiles identified in the research were regularly updated. They primarily included the following contents: bank offers (e.g. a promotional interest rate of savings accounts, loans, etc.), organizational issues (e.g. disrupted access to electronic banking), information about sponsorship activities or other operations related to corporate social responsibility, promotion of new forms of payment (e.g. Blink), safety measures with electronic banking, and encouragement to regular saving (e.g. interesting publications of Getinbank - webinars on the psychology of saving). In an attempt to activate Internet users, surveys were used, e.g. a question from PKO BP: „Holiday in Poland or abroad?”, encouraging the profile's fans to discuss. On Fat Thursday, BZ WBK asked its followers about their preferences: donuts or angel wings? This question was tagged with the following note: „Regardless of your choice, remember that you can pay for your sweets with your mobile".

Interestingly, the size of the bank had no impact on the number of Facebook followers. Table 2 presents the combined number of likes and followers on all identified profiles in the network. mBank has the most fans whereas the largest Polish bank - PKO BP, ranks 6th in terms of the number of fans.

14 banks have a profile on Twitter. Due to the nature of the network itself, predominant posts (tweets) are short communiques. This network is most frequently used to communicate with investors or journalists rather than clients themselves. There are also repeats of many contents from Facebook. mBank has the most publications in this network (101,400 tweets), while ING Bank Śląski has the most followers - 17,000 (a detailed index is included in Table 2).

All the researched banks had their channels on YouTube. In the case of a presence in this network, the number of subscribers of a given channel mattered less (ING Bank Śląski has the most) than the range of clips measured, among others, in the total number of views. The most frequently watched clip was published by Bank Handlowy w Warszawie - with over 4 million views. All the channels where clips had been uploaded were divided into topical playlists. These mainly covered topics such as: home finances, electronic banking instructions, promotion (advertising spots familiar from television, at times in an extended version), or the CSR. Some banks have found another use for YouTube. For instance, Bank Millennium uploads broadcasts from the board's press conferences on the presentation of financial results, among others (these clips are twenty-something minutes long). Bank Ochrony Środowiska, on the other hand, has a corporate foundation channel. BZ WBK adjusted a section of their clips to the needs of people with various disabilities: for the deaf using sign language clips with an interpreter, for the deaf with subtitles, for the visually impaired clips with an embedded audio description.

10 banks had profiles on another analyzed social network, Instagram. Idea Bank had the most published posts (521) whereas ING Bank Ślaski had the most followers $(4,219)$. In the case of Instagram, it is vital to focus on the visual aspect that would be less invasive in terms of commercial contents. Hence, it often features posts related to sponsorship or other CSR activities as well as contests. Two profiles stand out in this network. Idea Bank presents the Idea Hub project - the idea of co-working - a shared office space for the bank's clients which is available 
in 6 cities (Warsaw, Łódź, Kraków, Wrocław, Poznań and Katowice). Credit Agricole Polska, on the other hand, promotes its Discount Club (Klub Rabatowy Banku Credit Agricole) via its profile @klubrabatowy - the clients can get discounts in over 10,000 places in Poland if they pay using the bank's card.

It is worth mentioning two cases among other activities of banks in social media. The first one is the PKO BP project - School Blogs (szkolneblogi.pl). It is a blogging platform for school saving banks which elaborates on the idea of the program dedicated to schools, announces contests and presents interesting facts from "the world of kids' finances". When the publication was being drafted, the platform included 742 blogs. In the second case, BZ WBK created its own social network - the Bank of Ideas (bankpomyslow.bzwbk.pl). The network is dedicated to the bank's clients who have ideas on how to improve their bank. One can submit their ideas, comment on others as well as win prizes for the best ideas. It is an interesting initiative in that the bank, aside from interacting with its clients, gets a number of interesting ideas for free which it can later implement in order to raise the quality of its services.

\section{Summary}

The conducted research has illustrated that the largest banks operating in Poland use social media quite actively in their communication with individual groups of stakeholders, and primarily with their clients. From the point of view of marketing communication, one can learn about these profiles via the company website (dedicated plugins) or from various other profiles thanks to cross-media activities. The most common mistake was too many promotional posts and too few activities aimed at an interaction with clients. The rule 70-20-10 may be useful here, where $70 \%$ of the content should feature information valuable to fans, $20 \%$ links to the contents generated by other users, and only $10 \%$ should be information about promotions and commercial contents (Adamiec, 2016). Despite these issues, it can be concluded that banks are trying to use the potential for social media in building relationships with clients, which is illustrated by numerous non-standard initiatives implemented by a section of the institutions.

\section{References}

Adamiec, T. (2016). 15 sposobów na wykorzystanie mediów społecznościowych w biznesie. Retrieved from: http://czaplicka.eu/15sposobow-na-wykorzystanie-mediow-spolecznosciowych-w-biznesie (17.08.2016).

Budziewicz-Guźlecka, A. (2017). Role of the Sharing Economy in the Contemporary Economy. Ekonomiczne Problemy Usług, 1 (126), 27-36.

Cabosky, J. (2016). Social media opinion sharing: beyond volume. Journal of Consumer Marketing, 3 (33), 172-181.

Drab-Kurowska, A. (2013). The role of social media in economy. Zeszyty Naukowe Uniwersytetu Szczecińskiego, 763.

Kaplan, A.M., Haenlein, M. (2010). Users of the World, Unite! The Challenges and Opportunities of Social Media. Business Horizons, 53.

Komisja Nadzoru Fiansowego (2018). Retrieved from: https://www.knf.gov.pl/?articleld=56224\&p_id=18.

Levy, M. (2009). Web 2.0 Implications on Knowledge Management. Journal of Knowledge Management, 1 (13), $120-134$.

Levinson, J.C., Gibson, S. (2011). Marketing partyzancki w mediach społecznościowych. 126 narzędzi w walce o pozycję w Internecie. Transl. by M. Grala-Kowalska. Warszawa: Wolters Kluwers.

McQuail, D. (2007). Teoria komunikowania masowego. Translated M. Bucholc, A. Szulżycka. Warszawa: Wydawnictwo Naukowe PWN.

Social Banking: Leveraging Social Media to Enhance Customer Engagement (2014). Retrieved from: https://www.capgemini.com/ resource-file-access/resource/pdf/social_banking_leveraging_social_media_to_enhance_customer_engagement.pdf.

Wiktor, J.W. (2013). Komunikacja marketingowa. Wydawnictwo Naukowe PWN.

Cite this article aS: Budziewicz-Guźlecka, A., Woźniakowski, M. (2018). Social media in the marketing communication of Polish banks. European Journal of Service Management, 1 (25), 23-29. DOI: 10.18276/ejsm.2018.25-03. 